\title{
Dangerous nuclear whispers
}

\author{
Voices within the Obama administration threaten to undermine non-proliferation efforts. \\ They should be ignored.
}

hop n April, US President Barack Obama told a crowd in Prague of his hope for a world free of nuclear weapons. Achieving such a vision would take "patience and persistence", he said. But we "must ignore the voices who tell us that the world cannot change".

Unfortunately, some of those voices belong to powerful figures within Obama's own administration. Last month, the non-proliferation news site Global Security Newswire reported that the defence secretary, Robert Gates, has been quietly lobbying for the reinstatement of a programme to build a new generation of 'reliable' nuclear warheads. The same report suggests he has at least tentative support from two key cabinet members: Secretary of State Hillary Clinton and energy secretary Steven Chu. However, pursuing this programme would do nothing to improve the reliability of the US nuclear arsenal. Instead, it would seriously damage Obama's efforts to reduce the threat posed by the world's most deadly weapons.

Since 1992, the United States has held a voluntary moratorium on nuclear testing. During that period, scientists at the nation's nuclearweapons laboratories have used computer simulations and non-nuclear tests to ensure that the existing weapons are safe and dependable.

During the administration of President George W. Bush, however, some weapons scientists sought to move beyond this post-cold-war caretaker role, and pushed for the development of low-yield and earth-penetrating nuclear weapons that could be used against conventional military targets. Congress halted those projects for fear they would rekindle the arms race. So the scientists came up with a supposedly more benign warhead concept. Dubbed the Reliable Replacement Warhead, it would require less maintenance than existing weapons, and would last longer. One argument was that the plutonium in current-generation weapons was degrading because of its own radioactivity, and that this, over time, would make the devices too unreliable to use. Another, which Gates repeated in a speech last October, was that the new weapons would not require testing. Ulti- mately, he asserted, such devices would allow the United States to further lower its nuclear stockpile.

Yet such arguments are spurious. Studies by the weapons labs themselves show that the nuclear material within existing devices will last for decades (see Nature 444, 660-661; 2006). Experienced nuclear-weapons scientists believe that it would be irresponsible to deploy a warhead without testing it first. And there is no reason that the stockpile could not be reduced without building a new nuclear warhead.

Gates is now leading a major administration review of the entire nuclearweapons complex, including the reliable-warhead proposal. That review comes at a crucial time for its non-prolif-

eration agenda. Obama is currently pursuing Senate ratification of the Comprehensive Nuclear-Test-Ban Treaty (CTBT), an international prohibition of nuclear-weapons testing. Next year, his administration will also take part in an international review of the Non-Proliferation Treaty, the main international tool to limit the spread of nuclear weapons. For the United States to be developing a new warhead during this period would look to other nations like rank hypocrisy. Moreover, the replacement programme's very conceit, that existing warheads may not be reliable for much longer, will probably fuel conservative resistance to ratification of the CTBT.

Hopefully, the nuclear review will decide against recommending any sort of replacement programme, 'reliable' or otherwise. But if it does not, then Obama should have the courage to reject the plan. The US nuclear stockpile is more than adequate to defend the nation's territory and that of its allies for decades to come. If Obama truly wishes to lead the world in nuclear disarmament, then he should do so with the warheads the nation already has.

\section{Cash costs}

\section{Massive funding for Pakistan's ailing universities holds many lessons for other developing nations.}

ight years ago, a task force advising Pakistan's former military ruler, General Pervez Musharraf, laid out a bold plan to revitalize the country's moribund research system: initiate a fivefold increase in public funding for universities, with a special emphasis on science, technology and engineering. The proposal was a radical departure from conventional wisdom on the economics of developing nations, which favours incremental investments. Sudden surges of cash are held to be dangerous in poorer countries, which often lack the institutions or the calibre of people required to make the most of such a windfall, and the money can easily be wasted or fall prey to corruption.

Nonetheless, Musharraf agreed to the proposal. The reforms began in 2003. And the results, which have now earned a qualified thumbsup from a group of experts in science and education policy (see page 38), offer some valuable lessons for other developing nations.

First, conventional wisdom isn't always right. Despite early doubts that Musharraf's autocratic regime could allocate the new funds effectively, the experts cite initiatives such as a free national digital library and high-speed Internet access for universities as examples of success, as well as new scholarships enabling more than 2,000 students to study abroad for PhDs - with incentives to return to Pakistan afterwards. And they acknowledge that the years of reform have coincided with increases in the number of Pakistani authors publishing in research 